\title{
Front Matter: Volume 11742
}

, "Front Matter: Volume 11742," Proc. SPIE 11742, Radar Sensor Technology XXV, 1174201 (30 April 2021); doi: 10.1117/12.2598576

SPIE. Event: SPIE Defense + Commercial Sensing, 2021, Online Only 


\section{PROCEEDINGS OF SPIE}

\section{Radar Sensor Technology XXV}

Kenneth I. Ranney

Ann M. Raynal

Editors

12-16 April 2021

Online Only, United States

Sponsored and Published by

SPIE 
The papers in this volume were part of the technical conference cited on the cover and title page. Papers were selected and subject to review by the editors and conference program committee. Some conference presentations may not be available for publication. Additional papers and presentation recordings may be available online in the SPIE Digital Library at SPIEDigitalLibrary.org.

The papers reflect the work and thoughts of the authors and are published herein as submitted. The publisher is not responsible for the validity of the information or for any outcomes resulting from reliance thereon.

Please use the following format to cite material from these proceedings:

Author(s), "Title of Paper," in Radar Sensor Technology XXV, edited by Kenneth I. Ranney, Ann M. Raynal, Proc. of SPIE 11742, Seven-digit Article CID Number (DD/MM/YYYY); (DOI URL).

ISSN: 0277-786X

ISSN: 1996-756X (electronic)

ISBN: 9781510643215

ISBN: 9781510643222 (electronic)

Published by

SPIE

P.O. Box 10, Bellingham, Washington 98227-0010 USA

Telephone +1 3606763290 (Pacific Time)

SPIE.org

Copyright (C) 2021 Society of Photo-Optical Instrumentation Engineers (SPIE).

Copying of material in this book for internal or personal use, or for the internal or personal use of specific clients, beyond the fair use provisions granted by the U.S. Copyright Law is authorized by SPIE subject to payment of fees. To obtain permission to use and share articles in this volume, visit Copyright Clearance Center at copyright.com. Other copying for republication, resale, advertising or promotion, or any form of systematic or multiple reproduction of any material in this book is prohibited except with permission in writing from the publisher.

Printed in the United States of America by Curran Associates, Inc., under license from SPIE.

Publication of record for individual papers is online in the SPIE Digital Library.

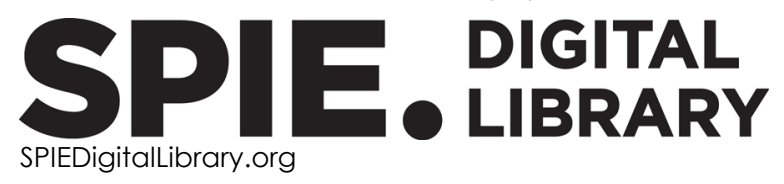

Paper Numbering: A unique citation identifier (CID) number is assigned to each article in the Proceedings of SPIE at the time of publication. Utilization of CIDs allows articles to be fully citable as soon as they are published online, and connects the same identifier to all online and print versions of the publication. SPIE uses a seven-digit CID article numbering system structured as follows:

- The first five digits correspond to the SPIE volume number.

- The last two digits indicate publication order within the volume using a Base 36 numbering system employing both numerals and letters. These two-number sets start with 00, 01, 02, 03, 04, 05, 06, 07, 08, 09, 0A, OB ... 0Z, followed by 10-1Z, 20-2Z, etc. The CID Number appears on each page of the manuscript. 


\section{Contents}

\section{ALGORITHMS AND PROCESSING I}

1174203 Time-frequency manifold representation for separating and classifying frequency modulation signals [11742-1]

1174204 On the use of MBPE to mitigate corrupted data in radar applications [1 1742-2]

1174206 Rotorcraft-borne 3D forward-looking MIMO SAR autofocusing [11742-4]

1174207 Symbolic dynamics for radar target maneuver detection [11742-5]

\section{ALGORITHMS AND PROCESSING II}

1174208 Deep complex neural network applications in remote sensing: an introductory review [11742-8]

1174209 Application of multidomain data fusion, machine learning and feature learning paradigms towards enhanced image-based SAR class vehicle recognition [11742-9]

11742 OC Distributed network communication using B.A.T.M.A.N. algorithm over LoRa [1 1742-12]

\section{SYSTEMS AND APPLICATIONS}

$11742 \mathrm{OE} \quad$ Software defined radar-based frequency modulated continuous wave ground penetrating radar [11742-14]

11742 OF Ultra-compact ultra-wideband radar for high-speed target tracking [11742-15]

11742 ol Tripartite correlation performance for use in quantum radar systems [1 1742-18]

\section{NON-LINEAR RADAR AND ARBITRARY WAVEFORMS}

$117420 \mathrm{~J} \quad$ Stimulating carrier modulation from electronics using a transverse electromagnetic cell [11742-19]

11742 OL Sudoku-based phase-coded radar waveforms [11742-21] 
11742 OM Ambiguity and Doppler tolerance analyses of frequency-stepped, Sudoku-variant waveforms [11742-22]

$11742 \mathrm{ON} \quad$ Analysis of planar arrays using Sudoku puzzles for multiple beamforming [11742-23]

\section{RF AND PHOTONIC DEVICES}

11742 OP Novel acceptor layer technology for diamond electronics (Invited Paper) [11742-24]

$117420 Q \quad$ Modeling diamond semiconductor transistors for millimeter wave power amplifier design (Invited Paper) [11742-25]

$11742 \mathrm{OU} \quad$ Uncooled, high-power, highly linear InGaAs photodiodes for Ku-band applications (Invited Paper) [11742-29]

\section{PHENOMENOLOGY}

1174211 Development of simulation and evaluation for high ice water content (HIWC) hazard detection using airborne radar [11742-36]

$1174212 \quad$ A high-precision SAR echo simulation method based on FDTD [11742-37]

1174213 Analysis of machine learning methods for clutter classification [11742-38]

\section{RADAR MICRO-DOPPLER}

1174214 Moving target S-Band radar data for Doppler and micro-Doppler analysis using a scale-model helicopter measured in a 100GHz compact radar range [11742-39]

1174215 Bird micro-Doppler simulation for bird versus UAV recognition [1 1742-40]

1174217 Tracking the dynamic motion of held objects using pulsed harmonic Doppler radar [1 1742-42]

$1174218 \quad$ Near real-time ASL recognition using a millimeter wave radar [11742-43]

JOINT SESSION WITH CONFERENCES SI205 AND SI208: MILLIMETER WAVE RADAR

1174219 R4AsH: a triple frequency laboratory radar for characterizing falling volcanic ash [11742-6]

11742 1A A third-order harmonic radar design for $\mathbf{m m}$-wave frequencies [11742-7]

iv 
$117421 \mathrm{~B} \quad$ Ultra-broadband voltage-controlled oscillator linearization for frequency modulated continuous wave MMW imaging systems [1 1742-52]

\section{POSTER SESSION}

$117421 \mathrm{C}$ Comments on rendering synthetic aperture radar (SAR) images [11742-44]

11742 1D Motion measurement impact on synthetic aperture radar (SAR) geolocation [1 1742-45]

$117421 \mathrm{E} \quad$ An efficient pulse detector and pulse width estimator for waveform characterization [1 1742-46]

$11742 \mathrm{lF} \quad$ Extraction of ground clutter return interference from downward-looking UWB radar signal [11742-47] 
Proc. of SPIE Vol. 11742 1174201-6

Downloaded From: https://www.spiedigitallibrary.org/conference-proceedings-of-spie on 26 Apr 2023 Terms of Use: https://www.spiedigitallibrary.org/terms-of-use 